\title{
Management of Recurrent Liposarcoma with Fractionated Stereotactic Radiotherapy: A Case Report
}

\section{Rekürren Liposarkomda Fraksiyone Stereotaktik Radyoterapi Uygulaması: Olgu Sunumu}

\author{
Gülhan Güler Avcı, Yıldız Yükselen Güney, Süheyla Aytaç Arslan, Ela Delikgöz Soykut, \\ Gonca Altınışık İnan
}

Dr. A. Y. Ankara Onkoloji Eğitim Ve Araştırma Hastanesi, Radyasyon Onkolojisi Kliniği, Ankara, Türkiye

doi: $10.5505 /$ aot.2012.83803

\section{ÖZET}

Bu olgu sunumunda nüks liposarkom tedavisinde farklı olarak cerrahi yapılmaksızın tek başına radyoterapi ile tümör kontrolü değerlendirilmiştir. İlk evresi T2bN0M0 olan iyi differansiye liposarkom tanılı, primer cerrahi uygulanan ve adjuvan radyoterapi uygulanmayan 40 yaşında kadın hastanın sol uyluk posteriorunda 5 yıl sonra nüks kitle gelişti. Nüks kitle için fraksiyone stereotaktik radyoterapi (FSRT) CyberKnife® (Accuray Inc., Sunnyvale, CA) ve mikroskopik hastalık için eksternal radyoterapi (ERT) uygulandi. Standart tedavi şekillerinin uygun olmadığı durumlarda FSRT ve/veya ERT tedavi alternatifi açısından umut verici olabilir, ancak daha çok çalışma ile desteklenmelidir.

Anahtar Kelimeler: Cyberknife; Stereotaktik Radyoterapi; Rekürren Liposarkom

\begin{abstract}
In this case report tumor control was evaluated with only radiotherapy without surgery in the management of recurrent liposarcoma. Recurrent mass on the left posterior thigh was developed in 40 years old woman whom surgery was performed without adjuvant chemotherapy for an initial stage of T2bN0M0 well-differentiated liposarcoma, 5 years after surgery. Magnetic resonance imaging (MRI) showed signs of recurrent mass $(38 \times 32 \times 15 \mathrm{~mm})$ in initial location. The patient was referred to our center for radiotherapy, since she did not accept surgery. We performed fractioned stereotactic radiotherapy (FSRT) with CyberKnife ${ }^{\circledR}$ (Accuray Inc., Sunnyvale, CA), for recurrent tumor and external beam radiation therapy (EBRT) for the microscopic tumor around the recurring mass. At 49 months follow-up MRI showed down sizing of tumor by $40 \%$. FSRT and/or EBRT may be a promising in terms of treatment alternative but this should be confirmed by more studies
\end{abstract}

Key words: Cyberknife; Stereotactic radiotherapy; Recurrent liposarcoma

\section{Giriş}

Liposarkom erişkinlerde oldukça s1k görülen yumuşak doku sarkomudur (YDS) ve tüm YDS'lerin dörtte birini oluşturur. Retroperitoneal bölge ve alt ekstremite en s1k yerleşim yerleridir. Olguların \%50'si uyluk yerleşimlidir. $\mathrm{Bu}$ bölgeden köken alan tümörler yavaş büyür ve genellikle ağrısızdır $(1,2)$.

Liposarkomda standart tedavi şekli cerrahidir. Temel cerrahi prensip, tümörün temiz cerrahi sınırların sağlanabildiği geniş rezeksiyon ile çıkartılmasıdır. Özellikle düşük gradlı ve $5 \mathrm{~cm}$ 'den küçük YDS tedavisinde, bu şekilde yapılan cerrahinin tek başına yeterli olduğu ve lokal nüks oranlarının \%10'ların altında olduğu bildirilmiştir $(2,3)$. Yang ve ark.'nın yayınladıkları çalışmada adjuvan radyoterapi (RT) lokal nüksleri azaltırken, genel sağkalımı (OS) değiştirmemiştir. Tümörün yüksek gradlı olması, derin yerleşimli olması ve yetersiz cerrahi yapılması lokal nüks ve tümöre bağlı ölümler üzerinde anlamlı prognostik faktörler olarak bulunmuştur (4).

$\mathrm{Bu}$ olgu ile nüks liposarkom tedavisinde eksternal RT (ERT) ve fraksiyone stereotaktik RT (FSRT) beraber kullanımı ile hedef hacimde daha yüksek RT dozu ve böylece lokal kontrolü sağlanan hastamızın 49 aylık izlem sonucunu sunmaktayız.

\section{Olgu Sunumu}


Kırk yaşındaki kadın hasta, kliniğimize sol uylukta nüks kitle şikayeti ile yönlendirildi. Hastanın sol uyluk posterioru yerleşimli kitlesi Kasım 2005 tarihinde marjinal eksizyon ile çıkarılmış, patolojik inceleme sonucunda iyi diferansiye liposarkom tanıs1 almıştı. Başlangıç evresi T2bN0M0 olan hasta adjuvan RT veya kemoterapi almamış ve 5 y1llik takipleri boyunca remisyonda izlenmişti.

Şubat 2010 tarihli kontrolünde çekilen uyluk manyetik rezonans görüntülemede (MRG) sol uyluk 1/3 orta kesiminde, düzgün konturlu $38 \times 32 \times 15 \mathrm{~mm}$ boyutlu lezyon saptanmıştı (Resim 1).

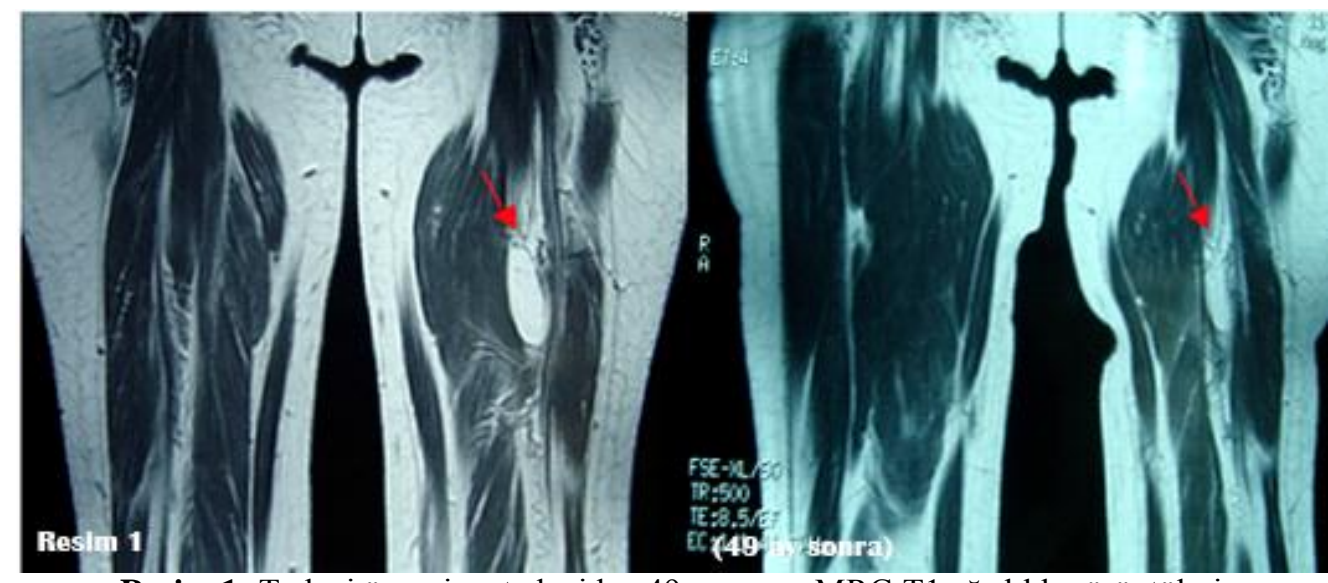

Resim 1: Tedavi öncesi ve tedaviden 49 ay sonra MRG T1 ağırlıklı görüntüleri

Cerrahiyi kabul etmeyen hasta lokal nüks bulgusu ile kliniğimize yönlendirildi. Hasta FSRT ve ERT programına alındı. Hasta, uygulanacak olan bu tedavinin etkinliğini destekleyen bilimsel kanttarın sınırlı olduğu konusunda bilgilendirildi.

Stereotaktik RT, CyberKnife ${ }^{\circledR}$ (Accuray Inc., Sunnyvale, CA), ile altın belirteç (fiducial) izleme yöntemi kullanılarak uyguland1. Tümör takibi için lezyon çevresine, bilgisayarlı tomografi (BT) eşliğinde dört adet altın belirteç yerleştirildi. Kişiye özel vakum yatak ile hasta stabilizasyonu sağlanarak supin pozisyonda pitch faktörü 1.8, kesit kalınlığ $1.5 \mathrm{~mm}$ olan kontrastsız planlama BT'si çekildi. RT öncesinde çekilmiş olan MRG görüntüleri ile planlama BT görüntüleri füzyon yapıldı. Uyluk MRG'sinde T1 kontrastlı incelemede görünen lezyon gros tümör volüm (GTV) (Resim 2) olarak konturlandı ve FSRT için GTV'e $3 \mathrm{~mm}$ emniyet sinırı verilerek planlanan target volüm (PTV; planlanan target volüm $=$ organ hareketleri ve set-up hataları için) (Resim 2) oluşturuldu. FSRT, ardışık günlerde beş fraksiyonda $\% 88$ izodoz ile 2800 cGy olarak uyguland1 (Resim 3).

Akut komplikasyon görülmeyen hastaya 3 hafta sonra ERT planlandi. ERT için ise GTV'ye $3 \mathrm{~cm}$ lateral-medial sınır, 5 $\mathrm{cm}$ kranio-kaudal sinır verilerek CTV (subklinik hastalık için klinik hedef volüm) ve $0.5 \mathrm{~cm}$ sinır verilerek PTV oluşturuldu. PTV $6 \mathrm{MV}$ foton ile konformal teknik ile 3500 cGy'de ERT uygulandı (3500 cGy, günlük $180 \mathrm{cGy} /$ fraksiyon). $\mathrm{Bu}$ olguda uygulanan FSRT (reçetelenen doz; 2800 cGy/ 5 fraksiyon) ve ERT (3500 cGy, 180 cGy/gün) tedavilerinin biyolojik efektif doz (BED2) tümör değerleri hesapland1 ve toplamda 79 Gy olarak bulundu. FSRT eklenmesi ile çevre organlar maksimum korunurken, hedef volümde yüksek dozlar sağland. Sistemik tedavi uygulanmayan hastanın 49 aylık izleminde herhangi bir komplikasyon görülmezken ve takip MRG'lerinde ilk bir yılda tedavi öncesine göre kitle boyutunda $\% 40$ gerileme saptand. Stabil hastalık olarak takip edildi ve uzak metastaz tesbit edilmedi. 


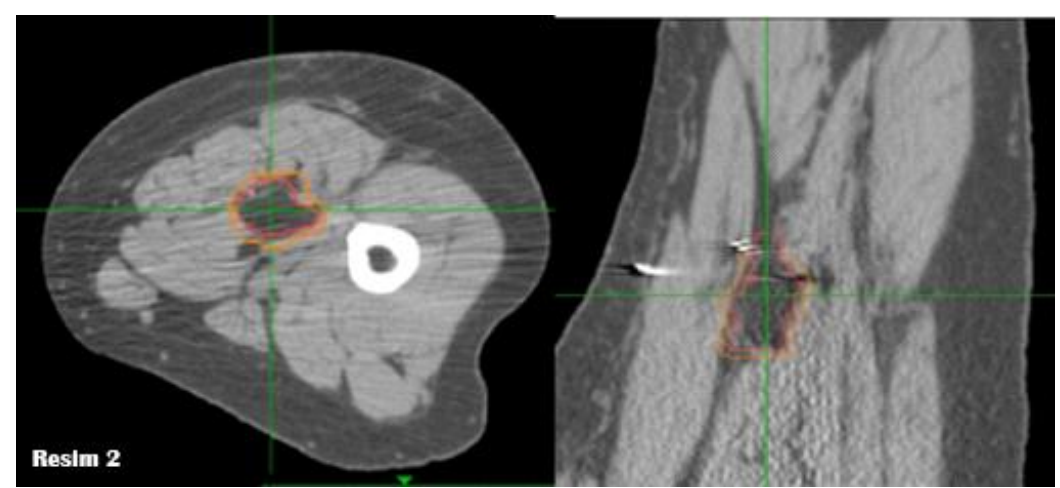

Resim 2: Aksiyel kesit, Koronal kesit, GTV; kırmızı, PTV; turuncu

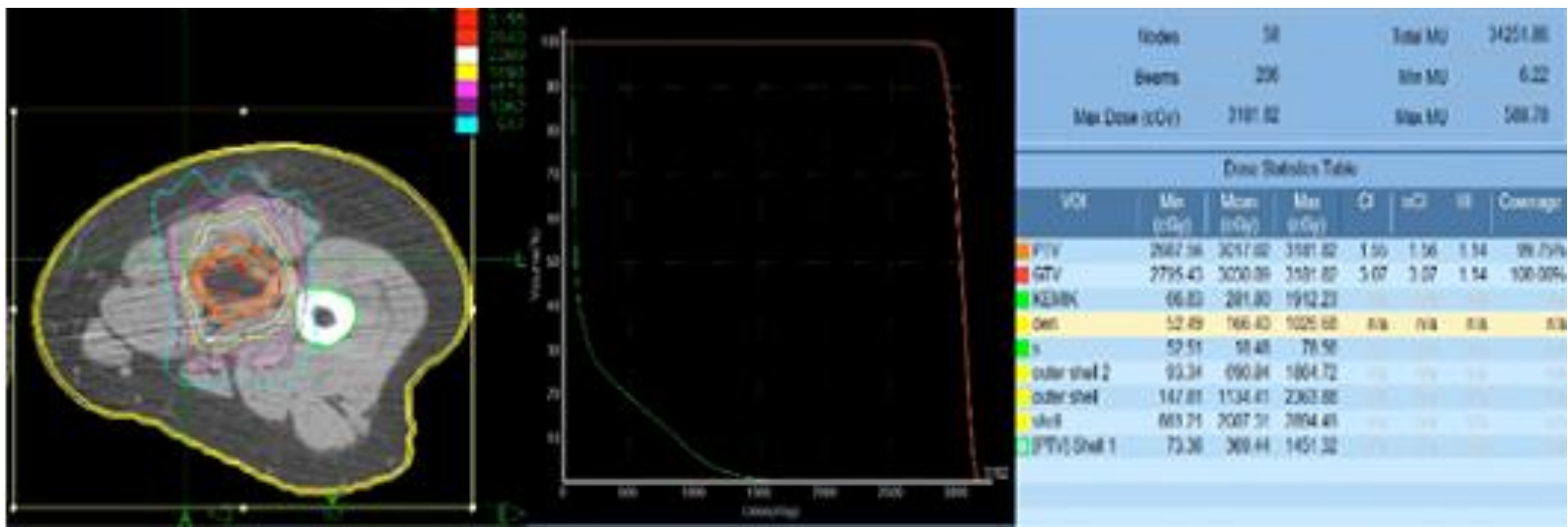

Resim 3: İzodoz Dağılımı, Doz Volüm Histogram, FSRT Planı

\section{Tartışma}

Liposarkom erişkinlerde sık olarak görülen YDS'ler arasindadir. Liposarkomlarda cerrahi, primer ve en etkin tedavi yöntemidir $(1,2)$. Tüm liposarkom tipleri için lokal nüks önemli bir problemdir ve \%40'a ulaşan oranlarda bildirilmektedir (1-4). RT, neoadjuvan veya adjuvan olarak uygulanabilir. YDS'ler radyoduyarlı olduğu klinik ve radyobiyolojik olarak kanıtlanmıştır. Ancak yüksek dozlarda RT sonrası regresyonunun yavaş olması nedeniyle, RT cevabı düşüktür $(3,4)$.

RT'nin amac1, mikroskopik rezidüel hastalığa karşı lokal kontrol sağlamaktır. RT intraoperatif, brakiterapi veya ERT şeklinde uygulanabilir (4-6). FSRT, YDS'lerde yaygın olarak uygulanmayan bir yöntemdir ve bu konuda çalışmalar kısıtlıdır. RT'nin lokal nüks oranını azalttığ1, OS oranını değiştirmediği birçok çalışma ile gösterilmiştir (4-6). İleriye dönük olarak yapılan bir çalışmada 164 YDS'li hasta, sadece cerrahi veya cerrahi ve adjuvan RT kollarına ayrıldı. Yüksek gradlı tümörlü hastalar için 5 yıllık lokal kontrol oranı RT kolunda \%89 iken; sadece cerrahi kolunda \%66 bulundu. İki grup arasında OS açısından farklılık saptanmadı (5). Diğer YDS'lerde olduğu gibi liposarkomda da nüksün en önemli belirteçleri tümörün gradı ve cerrahi sınırdır $(5,6)$.

Moureau-Zabotto ve ark.'lar1 izole lokal nüks YDS'li 83 hastayı geriye dönük inceledi. Tüm nüks olgularda cerrahi uygulanmıştı. Cerrahi ile mikroskopik olarak çıkarılamayan veya yakın cerrahi sınırı olan (1 mm'den az), ilk tedavisinde RT almayan toplam 23 hastaya ERT (ortalama doz: 55 Gy), 26 hastaya sadece brakiterapi (düşük doz Ir 192 -ortalama doz: 45 Gy) ve 4 hastaya da ERT ve brakiterapi uygulandi. Hastaların $\% 45$ 'inde relaps gelişti. Rekürrens tedavisinde re-rezeksiyon hastalıksız sağkalımı arttırdı. İkinci defa lokal nüks, RT uygulanan kolda \%37 iken; RT uygulanmayan kolda $\% 74$ bulundu. Re-irridasyon lokal kontrol oranını arttırdı. Beş yıllık OS \%54, lokal rekürrens oran $1 \% 35$ bulundu (7).

Tepper ve ark.' 'ları tarafindan yapilan bir çalışmada sadece RT (64 Gy üzeri) ile tedavi edilen YDS'li 51 hastanın 11'i (\%21) 5 
y1llık takipte hastalıksız yaşamakta idi. Beş cm'den küçük tümörlerde lokal kontrolün daha iyi olduğu bildirildi. Cerrahi yapılamayan ve tümör çapının $5 \mathrm{~cm}$ 'den küçük olduğu durumlarda, RT dozunun arttırılması (66 Gy ve üzeri) daha iyi lokal kontrol sağladı (8). Bizim olgumuzda da tümör çap1 5 cm'den küçüktü ve lokal kontrolü artırmak için FSRT ile daha yüksek dozda RT uyguland.

Dickie ve ark.'ları tarafindan, fonksiyon koruyucu cerrahi sonrası RT uygulanan 768 hasta geriye dönük olarak incelendi. Lokal nüks gelişen 60 hasta RT hacmi- nüks yeri ilişkisi açısından irdelendi. Lokal nüksler, 49 hastada (\%6.4) RT alanı içinde, 9 hastada $(\% 1.1)$ alan dışında ve 2 hastada $(\% 0.3)$ alan kenarında gelişmişti. Sonuçlar, tedavi hacmi iyi belirlendiğinde alan kenarındaki nükslerin çok az olduğuna işaret ediyordu. Bu çalışmayla ileri teknoloji ve görüntüleme kılavuzluğunda belirlenmiş hacimlerle RT uygulamasinın önemi vurgulanmıştır (9). Wulf ve ark.'nın bir çalışmasında 21 hastaya RT öncesinde veya sonrasında stereotaktik boost uygulandı. $\mathrm{Bu}$ hastalardan sadece biri paravertebral bölgede nüks etmiş liposarkom olgusuydu. Stereotaktik yöntem ile 3 fraksiyonda 1500 cGy, ERT ile 4500 cGy uygulanan nüks liposarkom tanilı bu hastada k1smi cevap alındı (10).

Bizim olgumuzda uygulanan FSRT ve ERT tedavilerinin biyolojik efektif doz (BED2) tümör değerleri 79 Gy idi. FSRT'nin eklenmesi ile çevre organlar maksimum korunurken, hedef volümde yüksek dozlar sağlandı. Olgumuzda, ilk bir yılda kitle boyutunda $\% 40$ gerileme saptand 1 ve 49 aylik izleminde stabil hastalık olarak takip edildi, uzak metastaz tespit edilmedi.

YDS'lerde lokal nüks durumunda uygulanacak tedavi tartışmalıdır. Ekstremite koruyucu tedavi uygulanabilecekse cerrahi ve RT kombine edilmelidir. Sonuç olarak FSRT ve/veya ERT; standart tedavi şekillerinin uygulanamadığı durumlarda tedavi alternatifi açısından umut verici bir seçenek olabilir. Ancak daha çok çalışma ile desteklenmelidir.

Çıkar Çatışması: Yok

\section{Kaynaklar}

1. Aksoy B, Aksoy HM. Bacakta sekonder deri tutulumlu rekürren miksoid liposarkom: Olgu sunumu. Genel Tip Dergisi 2009;19:33-5

2. $\mathrm{Ng}$ YC, Tan MH. Liposarcoma of the extremities: a review of the cases seen and managed in a major tertiary hospital in Singapore. Singapore Med J 2009;50:857-61

3. Shiu MH, Chu F, Castro EB, Hajdu SI, Fortner JH. Results of surgical and radiation therapy in the treatment of liposarcoma arising in an extremity. Am J Roentgenol Radium Ther Nucl Med 1975;123:577-82

4. Yang JC, Chang AE, Baker AR, et al. Randomized prospective study of the benefit of adjuvant radiation therapy in the treatment of soft tissue sarcomas of the extremity. J Clin Oncol 1998;16:197-203

5. Pisters PW, Harrison LB, Woodruff JM, Gaynor JJ, Brennan MF. A prospective randomized trial of adjuvant brachytherapy in the management of lowgrade soft tissue sarcomas of the extremity and superficial trunk. J Clin Oncol 1994;12:1150-5

6. Brennan MF, Casper ES, Harrison LB, Shiu MH, Gaynor J, Hajdu SI. The role of multimodality therapy in soft-tissue sarcoma. Ann Surg 1991;214:328-36

7. Moureau-Zabotto L, Thomas L, Bui BN, Chevreau C, Stockle E, Martel P. Management of soft tissue sarcomas (STS) in first isolated local recurrence: a retrospective study of 83 cases. Radiother Oncol 2004;73:313-9

8. Tepper JE, Suit HD. Radiation therapy alone for sarcoma of soft tissue. Cancer 1985;56:475-9

9. Dickie CI, Griffin AM, Parent AL, et al. The relationship between local recurrence and radiotherapy treatment volume for soft tissue sarcomas treated with external beam radiotherapy and function preservation surgery. Int $\mathrm{J}$ Radiat Oncol Biol Phys 2012;82:1528-34

10. Wulf J, Hadinger U, Oppitz U, Thiele W, Flentje M. Stereotactic boost irradiation for targets in the abdomen and the pelvis. Radiother Oncol 2004;70:31-6 